Миськовець Н. П., к.е.н. (Національний університет водного господарства та природокористування, м. Рівне)

\title{
ФІНАНСОВІ ВАЖЕЛІ ВПЛИВУ НА РОЗВИТОК ЕКОСИСТЕМНИХ ПІДПРИЕМСТВ
}

В статті здійснено ідентифікацію сутності поняття «фінансовий механізм». Автором проведено порівняльний аналіз важливих складових фінансового механізму, що визначають пріоритетність у діяльності підприємств. Розкрито фінансові важелі, які впливають на розвиток екосистемних підприємств.

Ключові слова: екосистемні підприємства, фінансові механізми, фінансові важелі, лісогосподарські, сільськогосподарські та рибогосподарські підприємства.

Вступ. Сучасні економічні умови господарювання, що характеризуються швидкістю зміни чинників зовнішнього середовища, посиленням інтеграційних процесів і конкуренції між учасниками ринку, вимагають від підприємств реального пошуку нових перспективних напрямів розвитку. На сьогодні в Україні відсутня чітка пріоритетність у веденні підприємницької діяльності, особливо у тих підприємств, які в процесі своєї діяльності залучають природні екосистеми. Підприємствам необхідно активно застосовувати у діяльності саме фінансові важелі, які безпосередньо впливають на кінцевий результат.

Значна частина вітчизняних підприємств сільського, лісового та рибогосподарського напряму господарювання перебуває у важкому стані, що пов'язано не стільки з дефіцитом фінансових ресурсів, скільки 3 низьким рівнем менеджменту та відсутністю обґрунтованих стратегій розвитку підприємства. Пріоритетності набуває проблема пошуку і вибору методів та інструментів, які б сприяли зміні культури ведення підприємницької діяльності. Одним з таких підходів може бути екосистемний підхід, який потребує комплексного поєднання фінансових важелів.

Аналіз останніх досліджень і публікацій. Питанням ефективного використання фінансових важелів у розвитку фінансовоекономічного механізму підприємств приділяли увагу багато вчених, зокрема Л. Дідик, Н. Власова, О. Круглова, Б. Райзенберг, Є. Стародубцев, Г. Семенов, Н. Богомолова, Т. Войтенко, Е. Чернодубов, І. Кома- 
рова ін. Питання, що стосується екосистемних підприємств, потребує подальших досліджень. Вдале застосування фінансових важелів у господарській діяльності сприятиме економічному зростанню та процвітанню екосистемних підприємств забезпечить населення продовольством, сприятиме задоволенню естетичних та моральних потреб.

Постановка завдання. Метою статті є здійснення ідентифікації сутності поняття «фінансовий механізм», розкриття всі складових фінансового механізму, зокрема фінансових важелів, котрі відіграють значну роль в діяльності екосистемних підприємств

Результати досліджень. Фінансові важелі $є$ одним з основних елементів фінансового механізму. В економічній літературі поняття «фінансовий механізм» використовується досить широко, але єдиної думки щодо його визначення та його складових не існує. Серед різноманіття визначень і підходів вчених та практиків до поняття «фінансовий механізм» найбільшої уваги заслуговують два аспекти до розуміння його суті.

Перший підхід полягає в тому, що під фінансовим механізмом розуміють функціонування самих фінансів підприємств. Матеріальним відображенням фінансових відносин $є$ грошові потоки. Організація цих потоків, порядок їх здійснення відбувається за певними правилами, певними напрямами, що і характеризує фінансову «техніку». Такий підхід до визначення фінансового механізму відображає внутрішню організацію функціонування фінансів підприємств.

Другій підхід до розгляду поняття «фінансовий механізм» полягає в тому, що його розуміють як сукупність методів і форм, інструментів, прийомів і важелів впливу на стан та розвиток підприємства. Даний підхід відображає зовнішню дію функціонування фінансів підприємств, характеризує фінанси як вирішальний фактор впливу апарату управління на економічний стан підприємства. Завдяки такому аспекту суті фінансового механізму необхідно чітко визначити його складові, структуру, основи та принципи формування. [1, С. 92]

Деякі автори [2] фінансовий механізм підприємства ототожнюють 3 фінансовим менеджментом і вважають, що це система управління фінансами, яка призначена для організації взаємодії фінансових відносин і грошових фондів з метою оптимізації їхнього впливу на кінцеві результати діяльності підприємства [2, С. 125 ].

М. Артус зазначає, що застосування фінансового механізму може досягти необхідного результату лише за рахунок доцільного спрямування взаємовпливу усіх його елементів на процес відтворення, передусім завдяки зворотному зв'язку елементів фінансового механізму різних вертикальних і горизонтальних рівнів, своєчасній 
реакції елементів вищого рівня на зміни, що відбуваються під впливом нижчого рівня [3, С. 56]. Розглянемо інші напрацювання науковців щодо даної проблематики у табл. 1.

Таблиця 1

Ідентифікація сутності поняття «фінансовий механізм»

\begin{tabular}{|c|c|}
\hline Джерело & Визначення \\
\hline 1 & 2 \\
\hline $\begin{array}{l}\text { О. Бандурка, } \\
\text { М. Коробов [4] }\end{array}$ & $\begin{array}{l}\text { Це сукупність конкретних форм і методів забезпечення розпо- } \\
\text { дільчих і перерозподільчих відносин, утворення доходів, фон- } \\
\text { дів грошових коштів }\end{array}$ \\
\hline М. Артус [3] & $\begin{array}{l}\text { Це фінансовий менеджмент, тобто схема управління фінанса- } \\
\text { ми, яка включає механізми управління фінансовими відноси- } \\
\text { нами і грошовими фондами }\end{array}$ \\
\hline $\begin{array}{l}\text { I. Зятковський } \\
\text { [5] }\end{array}$ & $\begin{array}{l}\text { Це сукупність форм і методів формування та використання фі- } \\
\text { нансових ресурсів для забезпечення фінансової діяльності } \\
\text { підприємства }\end{array}$ \\
\hline $\begin{array}{l}\text { А. Балабанов, } \\
\text { І. Балабанов [6] }\end{array}$ & $\begin{array}{l}\text { Це система дії фінансових важелів, які виражаються в плану- } \\
\text { ванні, організації, стимулюванні використання фінансових ре- } \\
\text { сурсів. Включає фінансові методи, фінансові важелі, норматив- } \\
\text { не, законодавче, інформаційне забезпечення }\end{array}$ \\
\hline $\begin{array}{l}\text { М. Грідчіна, } \\
\text { В. Захожай, } \\
\text { Л. Осіпчук [7] }\end{array}$ & $\begin{array}{l}\text { Це сукупність видів, форм і методів організації фінансових від- } \\
\text { носин }\end{array}$ \\
\hline В. Опарін [8] & $\begin{array}{l}\text { вляє сукупність фінансових методів і форм, інструмен- } \\
\text { ажелів впливу на соціально-економічний розвиток сус- } \\
\end{array}$ \\
\hline $\begin{array}{l}\text { Б. Райзенберг, } \\
\text { Л. Лозовський, } \\
\text { Є. Стародубцев, } \\
\text { П. Комарецька } \\
\text { [9] }\end{array}$ & $\begin{array}{l}\text { Це складова частина господарського механізму, сукупність } \\
\text { стимулів, важелів, інструментів, форм і способів регулювання } \\
\text { економічних процесів і відношень. Фінансовий механізм вклю- } \\
\text { чає, насамперед, ціни, податки, мита, штрафи, санкції, дотації, } \\
\text { субсидії, банківський кредит і депозитний відсоток, дисконтну } \\
\text { ставку, тарифи }\end{array}$ \\
\hline $\begin{array}{l}\text { А. Шеремет, } \\
\text { Р. Сайфулін [10] }\end{array}$ & $\begin{array}{l}\text { іння фінансовими відносинами через фінансові } \\
\text { могою фінансових методів }\end{array}$ \\
\hline $\begin{array}{l}\text { Н. Колчина, } \\
\text { Т. Поляк, } \\
\text { Л. Павлова [11] }\end{array}$ & $\begin{array}{l}\text { Це система управління фінансами підприємства з метою дося- } \\
\text { гнення максимального прибутку }\end{array}$ \\
\hline Л. Дідик [1] & $\begin{array}{l}\text { у встановлених державою форм та методів } \\
\text { ових відносин }\end{array}$ \\
\hline Г. Семенов [12] & $\begin{array}{l}\text { Являє собою систему економічних заходів (методів, інструмен- } \\
\text { тів і важелів), що функціонують в межах нормативно-правової } \\
\text { регламентації та спрямовані на забезпечення обслуговування } \\
\text { фінансовими ресурсами операційної, фінансової, інноваційної й } \\
\text { інших видів діяльності, передбачених власною фінансовою по- } \\
\text { літикою }\end{array}$ \\
\hline
\end{tabular}


продовження табл. 1

\begin{tabular}{|l|l|}
\hline \multicolumn{1}{|c|}{1} & \multicolumn{1}{|c|}{2} \\
\hline $\begin{array}{l}\text { В. Москаленко } \\
\text { 0. Шипунова } \\
\text { [13, С.11] }\end{array}$ & $\begin{array}{l}\text { Це система дії фінансових важелів, що виявляється в організа- } \\
\text { ції, плануванні і стимулюванні використання фінансових ресу- } \\
\text { рсів }\end{array}$ \\
\hline $\begin{array}{l}\text { Національна } \\
\text { економічна ен- } \\
\text { циклопедія [14] }\end{array}$ & $\begin{array}{l}\text { Це п'ять взаємопов'язаних елементів, які сприяють організації, } \\
\text { плануванню та стимулюванню використання фінансових ресур- } \\
\end{array}$ \\
& $\begin{array}{l}\text { са інфінансові методи, фінансові важелі, правове, нормативне } \\
\text { за допомогою яких забезпечується здійснення широкої системи } \\
\text { розподільчих відносин, утворення доходів та накопичень, ство- } \\
\text { рення та використання централізованих та децентралізованих } \\
\text { фондів грошових коштів }\end{array}$ \\
\hline
\end{tabular}

Досить широко розглядає поняття «фінансовий механізм» Г. Семенов [12]. Автор чітко визначає місце та конкретизує види фінансових важелів у системі фінансового механізму підприємства. Так, він зазначає, що фінансовий механізм підприємства включає визначену фінансовою політикою підприємства взаємодію:

- фінансових методів (фінансове планування, ціноутворення, інвестування, фінансування, страхування, кредитування, стимулювання і контроль);

- фінансових інструментів (перспективне, поточне і оперативне фінансове планування, види цін, фінансові ресурси, грошовий капітал, ревізія, фінансові стимули, фінансові санкції тощо);

- фінансових важелів, які конкретизують дію функціонування фінансового інструменту у фінансовому механізмі (баланс доходів і витрат, бізнес-план, цінові знижки і цінові надбавки, прибуток, внутрішній аудит, кредит, векселі, норми прискореної амортизації, страхові тарифи, норми штрафних санкцій, ліцензування, атестація, акредитація) в межах нормативно-правового регламентування [15, C. 136].

Отже, фінансовий механізм можна відобразити наступним чиHOM:

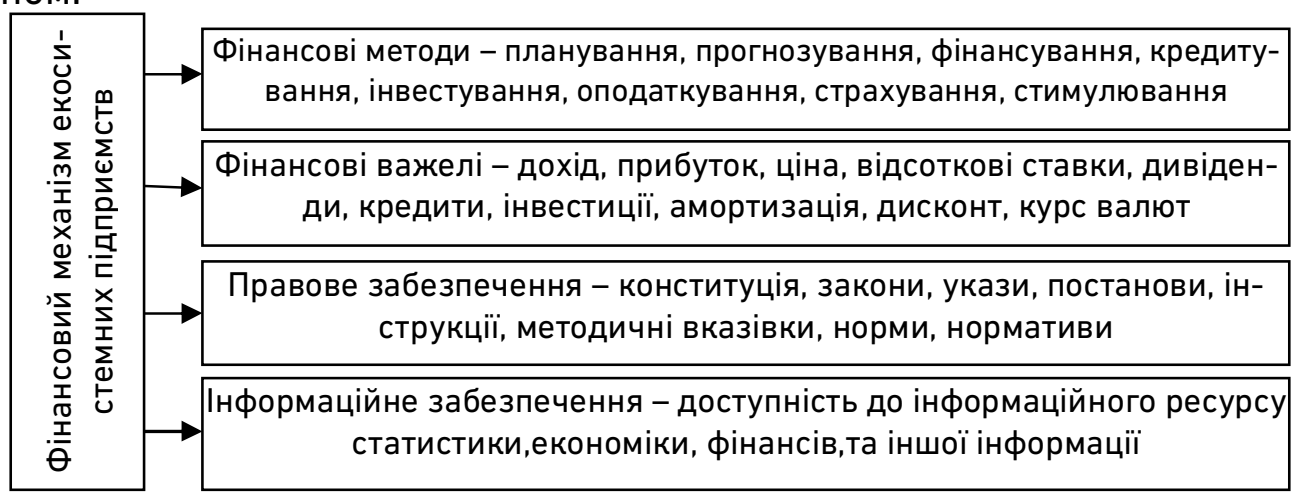

Рис. 1. Фінансовий механізм діяльності екосистемних підприємств 
Ми ж розглядаємо фінансовий механізм екосистемних підприємств як одне ціле, що включає фінансові методи, фінансові важелі, інформаційне та правове забезпечення на підприємстві й у державі. Зупинимося конкретніше на фінансових важелях.

Фінансові важелі $\epsilon$ ключовою складовою фінансового механізму, ядром якого має бути співпадіння фінансово-економічних інтересів безпосередньо підприємств та держави. Дослідження фінансових важелів як основного елементу фінансового механізму підприємства сприятиме формуванню засад сталого розвитку економічного сектору в цілому та всіх суб'єктів зокрема [16, С. 279].

Фінансові важелі представляють собою певну форму фінансово-економічних відносин, що становлять основу фінансового механізму підприємства (чи іншого економічного суб'єкта) та характеризують матеріальний вплив на економічні інтереси учасників ринкового простору. Фінансові важелі прямо чи опосередковано змінюють економічний процес, внаслідок чого відбуваються зрушення стимулюючого або навпаки - стримуючого характеру та формують умови та принципи функціонування та розвитку підприємства [16, С. 280].

Фінансові важелі $\epsilon$ системою фінансових показників, через які здійснюється вплив на господарську діяльність підприємства.

Чернодубов Е.В. [17, С. 46] як фінансові важелі розглядає податкову, інноваційну, інвестиційну, дивідендну кредитну політику, що також входять в структуру фінансового механізму, а Комарова І.В. [18] до низки фінансових важелів відносить встановлення державних дотацій, забезпечення фінансової підтримки, надання субсидій i пріоритетності державної підтримки, недопущення непродуктивних державних втрат, опрацювання ефективного інструментарію оподаткування та ін.

Фінансові важелі як категорія становить значний інтерес як у теоретичному, так і в практичному розрізі. Система фінансових важелів полягає в аналізі, оцінці та прогнозуванні їх впливу на результати діяльності підприємства та $€$ основою управління виробничою і фінансово-економічною діяльністю суб'єктів підприємництва, а динаміка показників, що їх характеризують, - предметом фінансового моніторингу [16, С. 278].

Фінансові важелі, які конкретизують дію функціонування фінансового інструменту у фінансовому механізмі (баланс доходів і витрат, цінові знижки і цінові надбавки, прибуток, внутрішній аудит, кредит, амортизація, страхові тарифи, норми штрафних санкцій тощо) в межах нормативно-правового регламентування, можна виділити в групи, що впливають на розвиток екосистемних підприємств (рис. 2). 


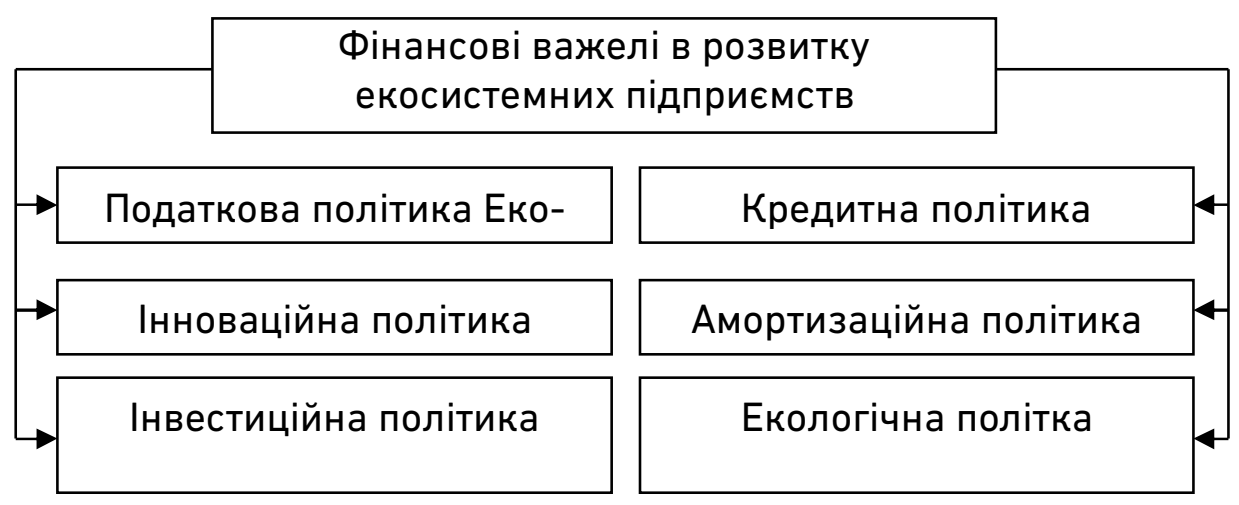

Рис. 2. Фінансові важелі в розвитку екосистемних підприємств

Доцільно більш детально розглянути групи, в які об'єднують фінансові важелі. Податкова політика в діяльності екосистемних підприємств виявляє свій вплив через ставки податків, податкові пільги, екологічний податок, рентну плату, рівень податкового тягаря, податкові ризики.

Інноваційна політика виявляється через інноваційний потенціал, інноваційну активність (рентабельність власного капіталу, економічна і екологічна ефективність). В сільському господарстві та рибництві до нині застосовуються застарілі технології, а впровадження інновацій завжди сприймається з підозрілістю, проте досвід застосування інновацій на рибогосподарських та сільськогосподарських підприємствах демонструє досить прогресивні результати.

Інвестиційна політика займає значне місце в діяльності підприємств, особливо це стосується лісогосподарських підприємств, коли зовнішні інвестиції грають ключову роль, адже фінансування таких підприємств відбувається переважно за рахунок держави та платників податків.

Кредитна політика екосистемних підприємств, зокрема в аграрному та рибогосподарському виробництві, практично всіх країн із розвинутою ринковою економікою має спеціалізовану систему сільськогосподарського кредиту. Це зумовлено специфікою сільського та рибного господарства, нестачею вільних фінансових коштів, високою капіталомісткістю і порівняно низькою фондовіддачею, сезонністю виробництва та значною тривалістю виробничого циклу. Ще однією особливістю екосистемних підприємств, яка впливає на специфіку кредитування, $\epsilon$ залежність від природно-кліматичних умов.

На кредитування впливають і порівняно малі розміри екосистемного підприємства, що робить їх менш конкурентоспроможними на ринку коротко- і довготермінових кредитів. Тобто кредитна політика 
екосистемних підприємств - це термін кредиту, стандарти кредитоспроможності, знижки, період окупності інвестицій в дебіторську заборгованість.

Екологічна політика на екосистемних підприємствах відіграє ключову роль, адже всі екосистемні підприємства використовують природні ресурси або цілі екосистеми та повинні дбати про проведення екологічних заходів і вести свою діяльність за екосистемним підходом, що впливатиме на якість сировини та стан природних ресурсів.

Амортизаційна політика підприємства $є$ цілеспрямованою діяльністю підприємства з вибору та застосування одного з можливих методів амортизації з метою максимізації обсягу власних фінансових ресурсів протягом амортизаційного періоду. Основне питання амортизаційної політики - який метод амортизаційних відрахувань обрати. Так, метод прискореного зменшення залишкової вартості застосовується лише при нарахуванні амортизації до об'єктів основних засобів, що входять до груп 4 (машини та обладнання) та 5 (транспортні засоби). На основні засоби груп 1 (земельні ділянки) та 13 (природні ресурси) відповідно до пп. 145.1.7 Податкового кодексу амортизація не нараховується [19]. Формування ефективної амортизаційної політики на підприємстві можна вважати одним із факторів підвищення ефективності його роботи. Тому варто приділити особливу увагу вибору методу нарахування амортизації (і врахувати всі особливості цього процесу), встановленню оптимальних строків використання необоротних активів та їх ліквідаційної вартості, розробленню норм амортизаційних відрахувань, формуванню та використанню амортизаційного фонду.

Таким чином, за результатами аналізу фахової літератури можна зробити висновок про те, що фінансові важелі - це конкретні інструменти, що забезпечують ефективне функціонування фінансового механізму підприємства, і тільки збалансоване їх застосування може мати позитивні результати на екосистемних підприємствах.

1. Дідик Л. М. Фінансовий механізм управління діяльністю сучасного підприємства. Економічний вісник НГУ. 2011. № 2. 92-93. 2. Власова Н. О., Круглова О. А., Безгінова Л. І. Фінанси підприємств : навч. посібник. К. : Центр учбової літератури, 2007. 272 с. 3. Артус М. М. Фінансовий механізм в умовах ринкової економіки. Фінанси України. 2005. № 5. С. 54-59. 4. Бандурка О. М., Коробов М. Я. Фінансова діяльність підприємства : підруч. для студ. вищ. навч. закл., що навч. за освітньо-проф. програмою спеціаліста зі спец. «Фінанси», «Банківська справа», «Облік і аудит». 2-ге вид., перероб. і доп. К. : Либідь, 2003. 384 с. 5. Зятковський І. В. Теоретичні засади фінансів підпри- 
ємств. Фінанси України. 2000. № 4. С. 17-26. 6. Балабанов А. И., Балабанов И. Т. Финансы: учеб. пособие. СПб. : Питер, 2002. 188 с. 7. Фінанси (теоретичні основи) : підручник / Грідчіна М. В. та ін. ; під. кер-вом і за наук. ред. М. В. Грідчіної, В. Б. Захожая. К. : МАУП, 2002. С. 312. 8. Опарін В. М. Фінанси (загальна теорія) : навч. посібник. 2-ге вид., доп. і перероб. К. : КНЕУ, 2001. 240 с. 9. Райзенберг Б., Лозовський Л., Стародубцев Є., Комарецька П. Управління фінансовим потенціалом підприємств. URL: // avtoreferat.net/content/view/13888/46/ (дата звернення : 01.10.2018). 10. Шеремет А. Д., Сайфулин Р. С. Финансы предприятий: учеб. пособие. М. : ИНФРА-М, 1999. 343 с. 11. Финансы предприятий : учебник для вузов / Колчина Н. В., Поляк Т. Б., Павлова Л. П. и др. 2-е изд., перераб. и доп. М. : ЮНИТИ-ДАНА, 2001. 447 с. 12. Семенов Г. А. Фінансове планування і управління на підприємствах : навч. посібник. К. : Центр учбової літератури, 2007. 432 с. 13. Москаленко В. П., Шипунова О. В. Финансово-экономический механизм промышленного предприятия : монографія. Суми : Довкілля, 2003. 176 c. 14. Національна економічна енциклопедія. URL: http://vocable.ru/ (дата звернення : 01.10.2018) 15. Войтенко Т. С., Гнатенко О. А. Місце фінансових важелів у функціонуванні фінансового механізму підприємства. URL: http://www.rusnauka.com (дата звернення : 01.10.2018) 16. Богомолова Н. I. Фінансові важелі в системі формування показників діяльності підприємства. Збірник наукових праць Державного економіко-технологічного університету транспорту. Економіка і управління. 2014. Вип. 27. С. 277-281. 17. Чернодубов Е. В. Інструменти адаптивного фінансового механізму забезпечення прибутковості підприємств. Науковий вісник: Фінанси, банки, інвестиції. 2013. № 3. С. 44-49. 18. Комарова І. В. Фінансові важелі державного регулювання фінансового сектору. Вісник Бердянського університету менеджменту і бізнесу. 2013. № 1. С. 80-84. 19. Податковий кодекс України : Закон України від 02.12.2010 № 2755-VI зі змінами та доповненнями. URL: http://zakon0.rada.gov.ua (дата звернення : 01.10.2018).

\section{REFERENCES :}

1. Didyk L. M. Finansovyi mekhanizm upravlinnia diialnistiu suchasnoho pidpryiemstva. Ekonomichnyi visnyk NHU. 2011. № 2. 92-93. 2. Vlasova N. 0., Kruhlova O. A., Bezghinova L. I. Finansy pidpryiemstv : navch. posibnyk. K. : Tsentr uchbovoi literatury, 2007. 272 s. 3. Artus M. M. Finansovyi mekhanizm v umovakh rynkovoi ekonomiky. Finansy Ukrainy. 2005. № 5. S. 54-59. 4. Bandurka O. M., Korobov M. Ya. Finansova diialnist pidpryiemstva : pidruch. dlia stud. vyshch. navch. zakl., shcho navch. za osvitno-prof. prohramoiu spetsialista zi spets. «Finansy», «Bankivska sprava», «Oblik i audyt». 2-he vyd., pererob. i dop. K. : Lybid, 2003. 384 s. 5. Ziatkovskyi I. V. Teoretychni zasady finansiv pidpryiemstv. Finansy Ukrainy. 2000. № 4. S. 17-26. 6. Balabanov A. Y., Balabanov Y. T. Fynansy: ucheb. posobie. SPb. : Piter, 2002. 188 s. 7. Finansy (teoretychni osnovy) : pidruchnyk / Hridchina M. V. ta in. ; pid. ker-vom i za nauk. red. M. V. Hridchinoi, V. B. Zakhozhaia. K. : MAUP, 2002. 
S. 312. 8. Oparin V. M. Finansy (zahalna teoriia) : navch. posibnyk. 2-he vyd., dop. i pererob. K. : KNEU, 2001. 240 s. 9. Raizenberh B., Lozovskyi L., Starodubtsev Ye., Komaretska P. Upravlinnia finansovym potentsialom pidpryiemstv. URL: // avtoreferat.net/content/view/13888/46/ (data zvernennia : 01.10.2018). 10. Sheremet A. D., Saifulyn R. S. Fynansy predpriiatii: ucheb. posobye. M. : INFRA-M, 1999. 343 s. 11. Fynansy predpriiatii : uchebnik dlia vuzov / Kolchina N. V., Poliak T. B., Pavlova L. P. y dr. 2-e yzd., pererab. y dop. M. : YuNITI-DANA, 2001. 447 s. 12. Semenov H. A. Finansove planuvannia i upravlinnia na pidpryiemstvakh : navch. posibnyk. K. : Tsentr uchbovoi literatury, 2007. 432 s. 13. Moskalenko V. P., Shypunova O. V. Finansovo-ekonomycheskii mekhanizm promyshlennoho predpriiatiia : monohrafiia. Sumy : Dovkillia, 2003. 176 s. 14. Natsionalna ekonomichna entsyklopediia. URL: http://vocable.ru/ (data zvernennia : 01.10.2018). 15. Voitenko T. S., Hnatenko 0 . A. Mistse finansovykh vazheliv u funktsionuvanni finansovoho mekhanizmu pidpryiemstva. URL: http://www.rusnauka.com (data zvernennia : 01.10.2018). 16. Bohomolova N. I. Finansovi vazheli v systemi formuvannia pokaznykiv diialnosti pidpryiemstva. Zbirnyk naukovykh prats Derzhavnoho ekonomiko-tekhnolohichnoho universytetu transportu. Ekonomika i upravlinnia. 2014. Vyp. 27. S. 277-281. 17. Chernodubov E. V. Instrumenty adaptyvnoho finansovoho mekhanizmu zabezpechennia prybutkovosti pidpryiemstv. Naukovyi visnyk: Finansy, banky, investytsii. 2013. № 3. S. 44-49. 18. Komarova I. V. Finansovi vazheli derzhavnoho rehuliuvannia finansovoho sektoru. Visnyk Berdianskoho universytetu menedzhmentu i biznesu. 2013. № 1. S. 80-84. 19. Podatkovyi kodeks Ukrainy : Zakon Ukrainy vid 02.12.2010 № 2755-VI zi zminamy ta dopovnenniamy. URL: http://zakon0.rada.gov.ua (data zvernennia : 01.10.2018).

Рецензент: к.е.н., доцент Мельник Л. В. (НУВГП)

Myskovets N. P., Candidate of Economics (Ph.D.) (National University of Water and Environmental Engineering, Rivne)

\section{FINANCIAL IMPACTS ON THE DEVELOPMENT OF ECOSYSTEM ENTERPRISES}

The article identifies the essence of the concept of «financial mechanism». The author carried out a comparative analysis of important components of the financial mechanism, which determine the priority in the activities of enterprises. Financial levers that influence the development of ecosystem enterprises are disclosed. 
Keywords: ecosystem enterprises, financial mechanisms, financial levers, forestry, agricultural and fishery enterprises.

Мисковец Н. П., к.е.н. (Национальный университет водного хозяйства и природопользования, г. Ровно)

\section{ФИНАНСОВЫЕ РЫЧАГИ ВЛИЯНИЯ НА РАЗВИТИЕ ЭКОСИСТЕМНЫХ ПРЕДПРИЯТИЙ}

В статье определяется суть концепции «финансового механизма». Автор провел сравнительный анализ важных компонентов финансового механизма, определяющих приоритет в деятельности предприятий. Раскрываются финансовые рычаги, влияющие на развитие экосистемных предприятий.

Ключевые слова: экосистемные предприятия, финансовые механизмы, финансовые рычаги, лесохозяйственные, сельскохозяйственные и рыбохозяйственные предприятия. 